\title{
Agricultural tractors conformity to the Brazilian traffic lighting and signaling legislation
}

\author{
Sabrina Dalla Corte Bellochio ${ }^{1^{*}}$ (i) Airton dos Santos Alonço ${ }^{1}$ \\ Tiago Rodrigo Francetto ${ }^{1}$ (D) Lutiane Pagliarin ${ }^{2}$
}

${ }^{1}$ Programa de Pós-graduação em Engenharia Agrícola, Universidade Federal de Santa Maria (UFSM), 97105-900, Santa Maria, RS, Brasil. E-mail: bellochiosabrinad@hotmail.com. ${ }^{*}$ Corresponding author.

${ }^{2}$ Mechanical Engineer, Santa Maria, RS, Brasil.

ABSTRACT: Increasing the agricultural machinery visibility makes public roadways traffic safer by reducing the number of accidents and their severity. The study aimed to verify the compliance of new agricultural tractors with Brazilian law, given by, CONTRAN Resolution $N^{\circ}$ 454, NR12 and NR31, regarding the presence of lighting and signaling elements for traffic. The study was carried out in agricultural machinery dealers of seven brands, corresponding to 50 different models of new wheeled agricultural tractors. The items that was not present in total tractors sample are the rear position lamp, the reverse light and the rear retro-reflector. In addition, only one of the seven brands studied showed complete compliance with evaluated elements. Although, the Brazilian legislation specify the presence of lighting and signaling items for agricultural tractors traffic, there is not fully comply on tractors models analyzed and the Brazilian law are not homogeneously met by the agricultural tractor manufacturers in the verified sample, what can be leading to tractors traffic accident occurrences.

Key words: agricultural mechanization, safety, roadways.

Conformidade de tratores agrícolas à legislação brasileira de iluminação e sinalização para tráfego

RESUMO: Aumentar a visibilidade das máquinas agrícolas torna o tráfego em vias públicas mais seguro, reduzindo o número de acidentes e sua gravidade. O estudo teve como objetivo verificar a conformidade dos tratores agrícolas com a legislação brasileira, dada pela Resolução CONTRAN N $N^{\circ} 54$, NR12 e NR31, quanto a presençados elementos de iluminação e sinalização para o tráfego. O estudo foi desenvolvido em concessionárias de máquinas agrícolas de sete marcas, correspondendo a 50 modelos distintos de tratores agrícolas de pneus, novos. Os itens que não estavam presentes na totalidade de tratores avaliados foram a luz de posição traseira, a luz de marcha à ré e as faixas retrorrefletivas. Apenas uma das sete marcas estudas apresentou total conformidade dos itens avaliados. Apesar da legislação brasileira especificar a presença dos elementos de iluminação e sinalização para o tráfego de tratores em vias públicas, não há total conformidade nos modelos avaliados e a legislação não é cumprida de forma homogênea pelos fabricantes, o que pode estar relacionado à ocorrência de acidentes com tratores agrícolas no tráfego.

Palavras-chave: mecanização agrícola, segurança, rodovias.

Making vehicles safer means saving lives in traffic. In Brazil, there are, on average, two accidents with agricultural tractors every three days in federal highways. The main occurrence of accidents with agricultural tractors on public roads, is the collision (HARLAND et al., 2014; MACEDO et al., 2015a, 2015b, 2016). Tractors compliance with Brazilian traffic laws, as well as verification and maintenance in the lighting and signaling system can direct the accidents occurrence and injuries severity (REIS \& MACHADO, 2009; SANTOS et al., 2013).
With regard to Brazilian legislation for tractor traffic on public roadways, it is applicable National Traffic Council CONTRAN Resolution $N^{\circ} .454$ (2013) and National Regulations NR12 and NR31 (BRASIL, 2018a; 2018b). As for the number and content of the required lighting and signaling elements, these are equivalent in both standards and the items are contained in National Traffic Council Resolution. Considering that, this study aimed to verify the compliance of agricultural tractors with Brazilian law (Resolution CONTRAN N 454, NR12 
and NR31) regarding the presence of lighting and signaling elements to traffic.

The study was carried out in agricultural machinery dealers located at Rio Grande do Sul state central region. It corresponded to 50 different new wheeled agricultural tractors models, manufactured or assembled in the country in 2017. This delimitation was designed to evaluate the original factory characteristics. Seven agricultural tractors brands were evaluated, two belonging to the AGCO group: Massey Fergusson and Valtra; two from the CNH Industrial Group: Case IH and New Holland; Agrale; John Deere and LS Tractor. For subsequent comparison purposes, without judging the company's manufacturers of the covered brands or their dealers, they were randomly named Brand A, B, C, D, E, F and G. Furthermore, citing trademarks does not imply endorsement or recommendation by the authors.

According the referred Brazilian legislation, nine lighting and signaling elements were verified: dipped-beam light; upper-beam light; front direction indicator lamp; hazard warning signal; rear direction indicator lamp; rear-position lamp; stop lamp; reversing lamp and rear retro-reflector, showed in figure 1 . The procedure adopted for the data collection was visual inspection, which occurred directly, indicating the presence. In addition, the tractor images were photographed using the Sony Cyber-shot Dsc W120 7.2 Mega pixels digital camera.
Regarding the nine lighting and signaling elements evaluated in the 50 different tractor models, $67 \%$ of them are present in all verified models. The elements present in total tractor models evaluated are the dipped-beam light, upper-beam light, front direction indicator lamp, hazard warning signal, rear direction indicator lamp and stop lamp.

The elements that were not present in all evaluated tractors were the rear-position lamp, the reversing lamp and the rear retro-reflector. The reversing lamp and the rear retro-reflector were present in almost a third part of the sample, this low compliance could be due they are being required only by CONTRAN Resolution $\mathrm{N}^{\circ} 454$ (2013). In relation to the rear-position lamp, it was obtained $92 \%$ of the presence, in the evaluated models. According BARBIERI (2018), a $100 \%$ of tractors with power above $36.58 \mathrm{Kw}$ presented the rear-position lamp in his study.

CORREA et al. (2005) point out as a result of their verification of safety requirements on Brazilian agricultural tractors, that the headlamp is most frequently available. However, the stop lamp was present in $77 \%$ of the sample, the hazard warning signal in $64.5 \%$ and the direction indicator lamp in $54.8 \%$. The negative highlight is the absence of reversing lamp in $90.3 \%$ of the models that they evaluated. Comparing the results, it is clear the evolution in the presence of mandatory devices in agricultural tractors, but the compliance with the current Brazilian legislation is not total.

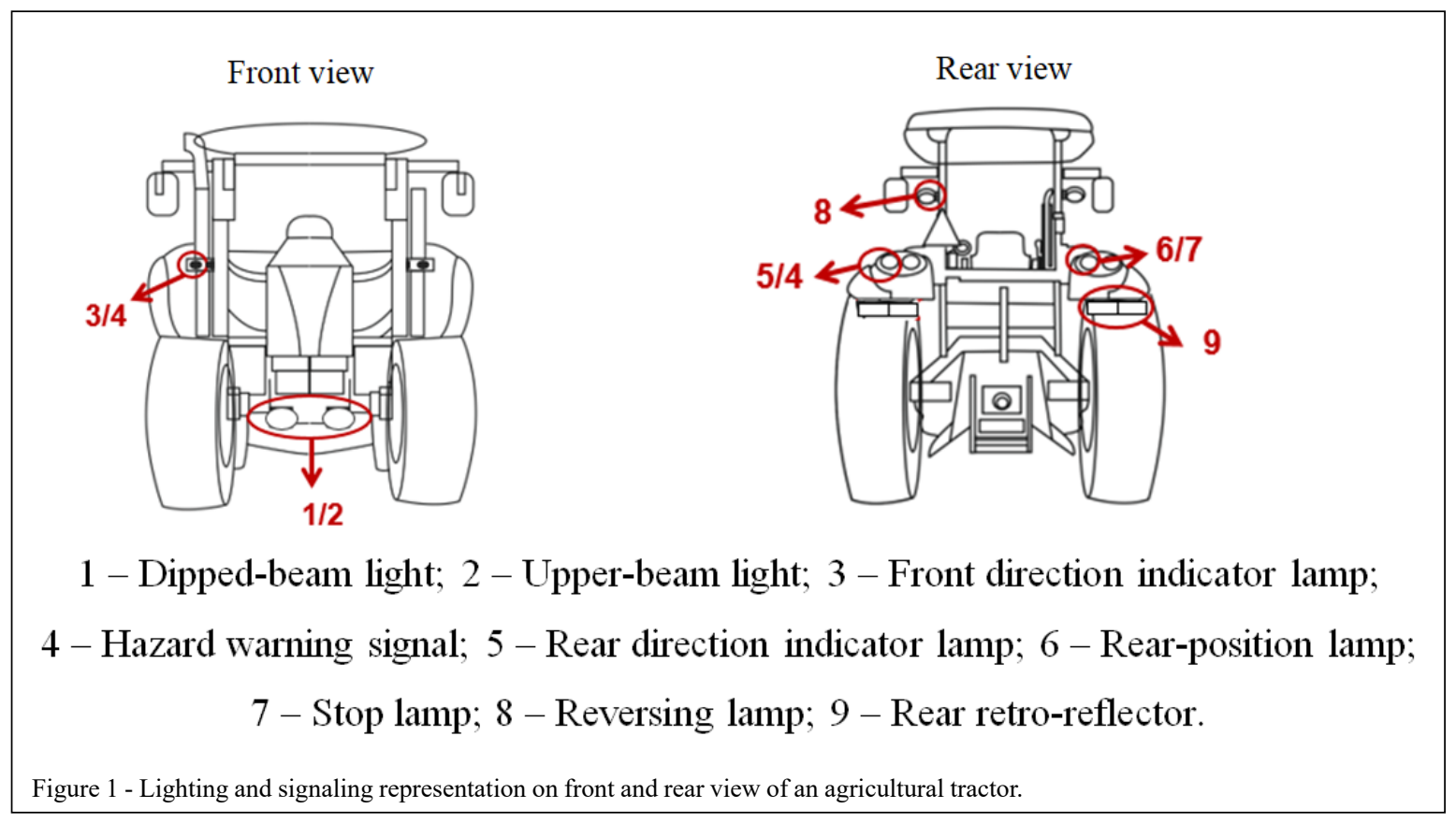

Ciência Rural, v.50, n.9, 2020. 
In relation to the agricultural tractors brands evaluated, together, they offer $68 \%$ of the 240 models marketed in the country, according to the Brazilian Tractors Yearbook (2017). Since Brazilian law is not fully met by the tractors manufactures evaluated, it is important to analyze the compliance provided by tractor brands. Figure 2 shows the information related to the presence percentage of the studied elements compliance, by evaluated brand.

The analysis of the information presented in figure 2 indicated that $86 \%$ of the brands studied do not comply with the legislation in the theme. Therefore, only Brand $\mathrm{E}$ offers in $100 \%$ of its models all lighting and signaling elements. This fact demonstrated that there is no supply uniformity by the manufacturing companies in lighting and signaling elements for traffic on agricultural tractors models. The agricultural machines manufacturers, despite knowing certain technical standards, do not use them in a correct and homogeneous way, what contribute to the tractors models offered in Brazil are not standardized (ALONÇO et al., 2006).

BAESSO et al. (2018) with the objective of observing the existence of ergonomics and safety items in agricultural tractors and comparing the results with the respective Brazilian laws, observed that $48 \%$ of the tractors studied did not meet these standards. Similar results occurred in studies by MATTAR et al. (2010) which determined the need for greater attention from national agricultural tractors manufacturers on occupational safety standards. In complement, rules, standardization and adherence to them may also lead to uniformity.

The greater adherence by tractors manufacturers to lighting and signaling standards can be correlated to the reduction of fatalities in accidents, since these elements provide a greater possibility of visualization of the agricultural tractor on the roadway (GKRITZA et al., 2010; GREENAN et al., 2016; RAMIREZ et al., 2016). However, the low enforcement of legislation related to the topic may be related to the result of not total manufacturers compliance on tractors lighting and signaling elements. According to the World Health Organization WHO (2015), the reduction of traffic accidents can occur through the application of road safety laws, which help to improve the users behavior.

Regardless of the consumer market, it is imperative that agricultural tractors manufacturers comply fully with applicable safety legislation

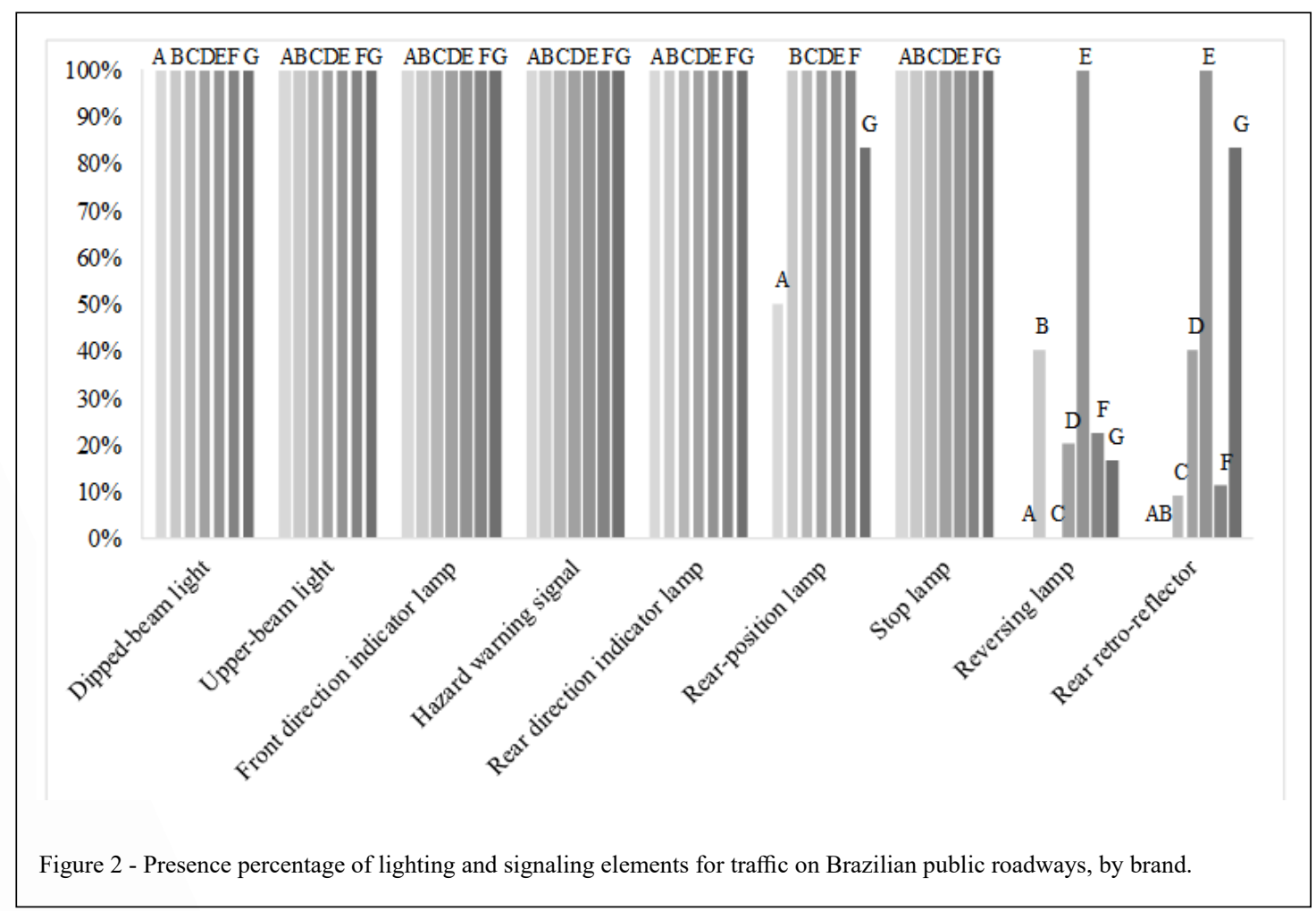

Ciência Rural, v.50, n.9, 2020. 
and standards in order to reduce possible causes of accidents. According to MATTAR et al. (2010), compliance with safety standards, allows better ergonomic conditions for agricultural tractors operators, acting as a preventive action against possible occupational accidents. It is important to emphasize that manufacturing companies operating in global markets must comply with the local markets regulations.

Although, the Brazilian legislation specify the presence of lighting and signaling items for agricultural tractors traffic, there is not fully comply on tractors models analyzed and the Brazilian law are not homogeneously met by the agricultural tractor manufacturers in the verified sample, what can be leading to tractors traffic accident occurrences.

\section{ACKNOWLEDGEMENTS}

The authors thank the Brazilian National Council for Scientific and Technological Development (CNPq) for funding the study and to Coordination for the Improvement of Higher Education Personnel (CAPES).

\section{DECLARATION OF CONFLICT OF INTERESTS}

The authors declare no conflict of interest. The founding sponsors had no role in the design of the study; in the collection, analyses, or interpretation of data; in the writing of the manuscript, and in the decision to publish the results.

\section{AUTHORS' CONTRIBUTIONS}

The authors contributed equally to the manuscript.

\section{REFERENCES}

ALONÇO, A. dos S. et al. Classification and identification of the graphic symbols used for the characterization of controls and commands in agricultural machines. Engenharia Agrícola, Jaboticabal, v.26, n.2, p.453-460, 2006. Available from: <https:// www.scielo.br/scielo.php? script $=$ sci_arttext\&pid $=$ S0100$69162006000200013 \& \operatorname{lng}=$ pt\&tlng=pt $>$. Accessed: Oct. 20, 2017. doi: 10.1590/S0100-69162006000200013.

BAESSO M. M. et al. Safety in the use of agricultural machines: evaluation of risk of accidents in rural work. Brazilian Journal of Biosystems Engineering, v.9, n.4, p.368-380, 2015. Available from: <http://seer.tupa.unesp.br/index.php/BIOENG/ article/view/622>. Accessed: Oct. 17, 2018. doi: 10.18011/ bioeng2018v12n1p101-109.

BARBIERI, J. P. et al. The development and validation of an ergonomics index for assessing tractor operator work place. Ciência Rural, v.48, n.1, 2018. Available from: <https:// www.scielo.br/scielo.php? script $=$ sci $\operatorname{arttext\& pid}=S 0103-$ $84782018000100352 \& \operatorname{lng}=$ en\&tlng=en $>$. Accessed: Nov. 07, 2018. doi: 10.1590/0103-8478cr20170218.
BRASIL. Portaria Ministério do Trabalho e Emprego n. 1086, de 18 de dezembro de 2018a. NR31 - Segurança e Saúde no Trabalho na Agricultura, Pecuária Silvicultura, Exploração Florestal e Aquicultura. Diário Oficial da União, Brasília, DF, 19 dez. 2018. Available from: <http://trabalho.gov.br/images/Documentos/SST/ NR/nr-31.pdf $>$. Accessed: Feb. 15, 2017.

BRASIL. Portaria Ministério do Trabalho e Emprego n. 1083, de 18 de dezembro de 2018b. NR12 - Segurança no Trabalho em Máquinas e Equipamentos. Diário Oficial da União, Brasília, DF, 19 dez. 2018. Available from: <http://www.trabalho.gov.br/ images//Documentos/SST/NR/NR12/NR-12.pdf >. Accessed: Feb. $15,2017$.

BRAZILIAN TRACTORS YEARBOOK 2017. Revista Cultivar Máquinas, ano 01, n. 01, 2017.

CONTRAN CONSELHO NACIONAL DE TRÂNSITO. Resolução n. 454, de 26 de setembro de 2013. Estabelece novos itens de segurança e dimensões para os tratores destinados a puxar ou arrastar maquinaria de qualquer natureza ou a executar trabalhos agrícolas e de construção, de pavimentação ou guindastes (máquinas de elevação) facultados a transitar em via pública. Diário Oficial da União, Brasília, DF, 02 out. 2013. Available from: <http://www.denatran.gov.br/resolucoes $>$. Accessed: Feb. 3, 2017.

CORREA, I. et al. 2005. Verificação de requisitos de segurança de tratores agrícolas em alguns municípios do estado de São Paulo. Revista Brasileira de Saúde Ocupacional, v.30, n.111, p.25-33, 2005. Available from: <https://www.scielo.br/scielo. php?script $=$ sci_arttext\&pid=S0303-76572005000100004\&lng $=$ pt\&tlng=pt $>$. Accessed: Aug. 07, 2018. doi: 10.1590/S030376572005000100004 .

GKRITZA K. et al. An empirical analysis of farm vehicle crash injury severities on Iowa's public road system. Accident Analysis and Prevention, n.42, p.1392-1397, 2010. Available from: <https://www.sciencedirect.com/science/article/abs/pii/ S0001457510000679?via\%3Dihub>. Accessed: Aug. 27, 2018. doi: 10.1016/j.aap.2010.03.003.

GREENAN, M. et al. The effects of roadway characteristics on farm equipment crashes: a geographic information systems approach. Injury Epidemiology, v.03, n.31, p.2-7, 2016. Available from: <https://injepijournal.biomedcentral.com/articles/10.1186/ s40621-016-0096-1>. Accessed: Nov. 06, 2018. doi: 10.1186/ s40621-016-0096-1.

HARLAND, K. K.; et al. Not just a rural occurrence: Differences in agricultural equipment crash characteristics by rural-urban crash site and proximity to town. Accident Analysis and Prevention, n.70, p.08-13, 2014. Available from: < https://www.sciencedirect. com/science/article/abs/pii/S0001457514000529?via\%3Dihub>. Accessed: Oct. 06, 2018. doi: 10.1016/j.aap.2014.02.013.

MACEDO D. X. S. et al. Characterization of accidents with farm machinery on federal highways in the state of Rio Grande do Sul, Brazil. Ciência Rural, v.45. n.01, p.43-46, 2015a. Available from: $<$ https://www.scielo.br/scielo.php?script=sci_arttext\&pid=S0103$84782015000100043 \& \operatorname{lng}=$ pt\&tlng=pt $>$. Accessed: Oct. 06, 2018. doi: $10.1590 / 0103-8478 \mathrm{cr} 20140333$.

MACEDO D. X. S. et al. Characterization of accidents involving tractors in Brazilian federal highways in the state of Minas Gerais. African Journal of Agricultural Research, v.10, n.31, p.30493055, 2015b. Available from: <https://academicjournals.org/ 
journal/AJAR/article-abstract/3F94A0654478>. Accessed: Oct. 07, 2018. doi: 10.5897/AJAR2015.10051.

MACEDO D. X. S. et al. Accidents with tractors on federal highways in the state of Goiás. Revista Energia na Agricultura, v.31, n.03, p.223-230, 2016. Available from: <http://energia.fca. unesp.br/index.php/energia/article/view/2387>. Accessed: Nov. 07, 2018. doi: 10.17224/EnergAgric.2016v31n3p223-230.

REIS, A. V. dos; MACHADO, A. L. T. 2009. Acidentes com máquinas agrícolas: Texto referência para técnicos e extensionistas. Pelotas: Ed. Universitária UFPEL, 2009. 103p.

SANTOS, V. C. dos; MONTEIRO, L., MACEDO, D. X. S. 2013. Precauções de Segurança durante a condução do trator.
In MONTEIRO, L. \& ALBIERO, D. Segurança na operação com máquinas agrícolas. Fortaleza: Imprensa Universitária, 2013. 124p

RAMIREZ, M. et al. Lighting and marking policies are associated with reduced farm equipment-related crash rates: A policy analysis of nine Midwestern US states. Occupational and Environmental Medicine, n.73, v.09, p.01-06, 2016. Available from: <https:// oem.bmj.com/content/73/9/621>. Accessed: Nov. 06, 2018. doi: 10.1136/oemed-2016-103672.

WHO, World Health Organization. Relatório global sobre o estado da segurança viária, 2015. Online. Available from: $<$ http://www.who.int/violence_injury_prevention/road_traffic/ en/>. Accessed: Jan. 31, 2017. 